\title{
Critical issues in recent developments in Reformational philosophy: a perspective ${ }^{1}$
}

\author{
Craig. G. Bartholomew \\ Centre for the Study of Religion \\ Cheltenham \& Gloucester College of HE \\ CHELTENHAM, UK
}

\begin{abstract}
Although the present is a time of great opportunity for Reformational thinking and activity, some Reformational philosophers are proposing a reconstruction of the tradition at the foundational level. Consequently, the present can also be seen as a time of crisis for the tradition as a whole. Proposed shifts are examined in the foundational areas of creation order, the antithesis and the authority of Scripture. These shifts are related to understandings of our context and thus the nature of modernity/postmodernity and its connection to these shifts also receives attention.
\end{abstract}

\section{Introduction}

For a life that has been opened up by the Spirit to the Lord Christ ${ }^{20}$ the project of Reformational philosophy is very attractive. A growing awareness of the comprehensive range of the rule of Christ alerted me to the importance of working in my field of specialisation, Old Testament theology, in an integrally Christian way. The neo-Calvinists showed me the theoretical nature of my work and highlighted the responsibility of integrally Christian theorising. The scaffolding and structural materials in my theory construction needed to be integrally Christian; in other words I needed the fruits of a Christian philosophy in my scholarship, and there was such a philosophy available, namely that of Dooyeweerd and Vollenhoven.

1 This paper was originally delivered as one of the Stoker lectures at PU for CHE in August 1994.

2 I am alluding here in particular to Paul's statement in Colossians 3:24 "you serve the LORD Christ." 
I have tried to take this direction seriously; it seemed to me that it would be tragic if I spent my life in academic service of the King with pagan ground motives skewing my scholarship from the inside and me oblivious of their effect. A lifetime of integrally Christian Old Testament scholarship was clearly the path to pursue, and consequently, I interrupted my work in Old Testament to spend a year at the Institute for Christian Studies (ICS) in Toronto, Canada in order to build philosophical foundations that would feed my scholarship in an integrally Christian way.

That was nearly two years ago. I have not lost the commitment to and the excitement of the neo-Calvinist vision. Indeed I would describe myself as Reformational and regard the legacy of Augustine, Calvin, Kuyper, Bavinck, Dooyeweerd and Vollenhoven as a great gift of God which we need to treasure and of course to develop and reform. At the heart of this tradition lies the biblical insight that "We could not establish any area of terrestrial life as an asylum for our autonomy with reference to the Creator. He has the right to all of our life, to all of our thought, and to all of our action. No sphere of life may be divorced from the service of God" (Dooyeweerd, 1954:5).

Elsewhere ${ }^{3}$ I have suggested that the present is a great time of opportunity for the Reformational tradition. Inter alia there is the door to Africa that is now open here in South Africa. The ongoing debacle in Rwanda, despite the Evangelical revival experienced there this century, has highlighted once again the desperate need in Africa for the large number of Christians to be equipped with an integral Christian worldview and to get this permeating every area of life in Africa in a redemptive way. The funeral of apartheid has taken place, and the opportunity is now before the Reformational community in South Africa to disentangle itself from apartheid ideology once and for all, and to make its treasure house of Reformational thinking available to Africa. One struggles to think of something more desperately needed in Africa than an integral worldview in the grip of the Bible and energised by a passion for the King ${ }^{4}$.

3 See Bartholomew (1994b).

4 My fundamentally positive orientation towards the Reformational tradition needs to be stressed, especially as this paper deals with the not-so-positive matter of critical issues in Reformational philosophy today. These issues seem to me to be critical precisely because I value the Reformational tradition so highly. 
ᄂ. G. Bartholomen

The entanglement of Reformational thinking with apartheid ideology has been deeply damaging to the cause of God's kingdom in Africa. However, my year at ICS alerted me to other developments in the Reformational community which seem to me as critical as the apartheid issue, and equally capable of derailing a seizing of present opportunities by the Reformational community. The remainder of this paper is devoted to outlining what I see as critical issues in recent developments in Reformational philosophy. My particular exposure has been to the Canadian scene, but I have also tried to read what I could of recent Dutch publications.

\section{Crisis of the tradition as a whole}

I have heard Calvin Seerveld say that the handing on of a tradition to the third generation is a critical time. De Vereniging voor Calvinistische Wijsbegeerte in the Netherlands recently celebrated its fiftieth anniversary - if one takes a generation as approximately 25 years then the present is that critical time of handing on. And that critical time is in danger of becoming a crisis time.

The ICS was established to do foundational theoretical work in the grip of a Reformational worldview. During my year there it became increasingly apparent to me that reconstruction was taking place at the philosophical and worldviewish levels; I would call what Hart and Olthuis, in particular, are up to, depth reconstruction. My point is that from influential members within the Reformational community we are facing a reassessment of the foundations of Reformational thinking.

The controversy at $\mathrm{ICS}^{5}$ has become focused on the homosexual issue. Hart in particular has emerged as a champion of gay and lesbian Christian relationships, marriages and ordination. Hart's position on the gay issue

5 It is important to note that not all the senior members at ICS are in agreement on the gay issue or the more fundamental shifts. ICS is divided over the gay issue and the more fundamental issues.

6 For Hart's written work in relationship to the gay issue see Hart (1989:217-230 1992a; 1993). His position on this controversial issue is not a recent development. At a service of the Metropolitan Community Church in Toronto in 1993 (the denomination for practising gays and lesbians), Hart received an award for his work on behalf of gays and lesbians over the last decade or so. Hart preached the sermon and presented his eschatological vision of the day when gays and lesbians would lead mainline denominations like his own (The Christian Reformed Church). 
seems to me a serious deviation from a biblical ethic ${ }^{7}$ but not the main issue in the present crisis in Reformational thinking in Toronto. As I see it, the gay issue is the tip of the iceberg that is visible above the waterline. The real shifts are the reconstruction work below the water level facilitating the shift on the homosexual issue. And these shifts are fundamental ones.

Some of the areas in which reconstruction is taking place are the following: the Reformational focus on the sovereignty of God, the foundational idea of God's good, unchanging creation order, the serious possibility of idolatry in a fallen world as articulated in the Reformational idea of the antithesis, the authority of Scripture and its function in relation to a Reformed worldview and philosophy, the vital importance of the development of integral Christian scholarship and institutions.

Below I will elaborate on these issues. It is worth noting here that these shifts are not confined to some members of the Canadian Reformational community. In preparation for this paper I have been struck by the similarities between Klapwijk's ${ }^{8}$ recent publications and the work of Hart. I am not suggesting that they are identical, but it is worth noting that both Hart and Klapwijk relate their reform of the Reformational tradition to our 'postmodern' context. Both propose changed understandings of the antithesis and its implications for Reformational philosophy. Klapwijk's preferral of 'transformation' is comparable to Hart's use of Rorty and ready embrace of postmodem philosophical developments (cf. Hart, 1992b). Both propose shifts in understanding of creation order and both appeal to Mekke's work in the process as a helpful alternative within the tradition.

7 Note that I do not have the space here for a thorough critique of Hart's position on homosexuality. Wolters (1993) is an excellent example of critique of Hart's attempts to read the Bible in such a way as to make room for Christian homosexual practice. It is important to note that neither Hart (1993:172) nor Olthuis (1992:1, 6) think that Scripture is positive towards same sex relations. Their shift on this issue comes mainly from their compassion for the gay community and their positive encounters with gay Christian couples. From this perspective Hart tries to find a way to read Scripture that allows for and supports such a shift. Postmodem notions of textual indeterminacy are invoked (Hart, 1992b:5, footnote 13; 1993:170, 171) and a pastoral strategy for reading the Bible developed (see section 5 below). In this paper these broader shifts that buttress Hart's move on the homosexual issue are analysed rather than the homosexual issue itself.

8 See Klapwijk 1987, 1988, 1989. 
There may well be many other points of contact between Hart and Klapwijk; suffice here to note the similarities.

It is obvious from the above that the analysis of the present crisis in Reformational thinking is no easy task. My procedure from here on is a modest one. I will focus on the three areas of creation order, the antithesis and the authority of Scripture with a view to demonstrating that there is a crisis of understanding in each of these foundational areas. Closely related to this crisis is the way in which we understand the challenge of our age i.e. the issue of modernity, postmodernity, and this will be my final area of focus.

\section{Creation order}

Within Reformational circles the controversy caused at the ICS June 1992 conference by Hart's and Olthuis' papers is now well known. With Olthuis' paper it was the homosexual issue which caused controversy, with Hart's it was creation order and his proposals for recentring Reformational philosophy in an ethos of compassion rather than creation order.

Hart (1992b) criticises Reformational understandings of permanent creation order along the following lines. Firstly a permanent creation order prevents followers of Christ from fully embodying an ethos of compassion. Indeed, "In this [Reformed] tradition the law-transcending ethos of compassion is held captive within an a-historical ethos of eternal, apriori, fixed, available order" (Hart, 1992b:3). Creation order is inherently conservative, tending to absolutise existing order and resisting radical reformation.

Secondly, Reformational understandings of permanent creation order have been deeply and negatively influenced by pagan notions of order. Accor-

9 I have focused on areas that seem to me to be of acute importance in Reformational thinking today. I am aware of the more specifically philosophical debates about anthropology, the supratemporality of the heart, the differentiation process in culture etc., but I have not attempted to deal with these issues in this paper. It should also be noted that although the title of this paper refers to Reformational philosophy, much of what I deal with is more readily categorised as the worldviewish foundations of Reformational philosophy. This is justified by the current reassessment of these foundations by Hart, Olthuis, Klapwijk etc. I am well aware of the debate about how worldview relates to philosophy (cf. Wolters, 1989). Whichever position one takes on this issue, the fact is that foundational issues which are at the heart of Reformational philosophy are being re-evaluated. 
Critical issues in Reformational philosophy: a perspective

ding to Hart (1992b:3) "Creation order in the Reformed tradition became the name for this entry of Western metaphysics into reading creation order in the Bible". Hart $(1992 \mathrm{~b}: 5,6)$ sees close connections between Reformed creation order and the logocentric realism of modernity. Philosophical realism is the source of the notion of a permanent ("universal, eternal, immutable, inviolable, rational" - Hart, 1992b:8) creation order and this was imported into Christian thinking through theology (Hart, 1992b:6). Such a permanent order is alien to a biblical ethos, which would encourage trust in God alone (Hart, 1992b:8). Both Reformed creation order and Thomistic eternal law are "a species of philosophical realism, of the Platonic heritage inside the Christian tradition" (Hart, 1992b:12).

Thirdly, Reformational understanding of permanent creation order skews our Bible reading because it prevents the Bible from casting light on contemporary issues like abortion, homosexuality, women's equality etc. (Hart, 1992b:4). An ethos of order also prevents us from seeing God as involved in all of life by making God into an absolutised projection of rational thought (Hart, 1992b:9).

Logocentrism is now being deeply questioned and undermined and, since creation order is so closely connected with it, it too must be reassessed. Hart proposes that we relativise order in Reformational thinking and that we recentre such thinking in an ethos of compassion. Christians are to be God's co-workers in creating a new order for our time:

As agents of freedom in the image of God, Jesus' followers are responsible
for creating new order as God's co-workers. And the God in whose presence
and under whose guidance we work is not immutable. ... Once order as spiri-
tual center is a dead end, we are spiritually free to make it relative to justice,
love, peace, and joy, and to reassign it for the inclusion of the marginalized
other who is different or has no power (Hart, 1992b:15, 16).

This may well involve, for example, redefining sexual morality. The litmus test of new order will be its ability to bear the fruit of love, justice and so on, i.e. to respond with compassion. "If within a present order in Christ we don't find life, we must seek a new order for life, again in Christ" (Hart, 1992b:20).

Reformational philosophy has developed around the law idea, and in this light it is not hard to see just how radical Hart's proposal is. His critique is foundational and his proposal amounts to a paradigm shift for the Reformational tradition. His foregrounding of compassion is laudable and his desire to be in touch with all forms of contemporary suffering alto- 
C. G. Bartholomew

gether commendable. Such concerns ought to be central to all Christian endeavour. But, is his critique of the Reformational tradition accurate and is his proposed recentring of the tradition the best way to promote love and compassion in our desperately needy world?

There is no doubt that the notion of creation order can be and has been used to justify terrible oppression (see Bartholomew, 1994a:66). However, it can also be used to undermine injustice, as I have argued in relation to the imago Dei and apartheid in South Africa (see Bartholomew, 1994a:66). Certainly, Hart's presentation of Reformed creation order is a caricature of the refined understanding of creation order in contemporary Reformational thinking. Three recent articulations of a Reformational perspective on creation order by Wolters (1994), Spykman (1992:178190) and Ouweneel (1993:251-292) are at pains to distance themselves from the Western metaphysical tradition and to articulate a Biblical understanding of creation order. Ouweneel (1993:266) and Wolters (1994:46) for example, recognise and avoid the rationalisation of order in the Greek Logos notion, which Hart (1992b:6) sees as part of the theological importation of rationalism into Christian thinking (cf. also Bartholomew, 1994a:64). Ouweneel $(1993: 251,259)$ stresses that it is only on the basis of Scripture that the Christian knows the cosmos as creational order and distinguishes this from the scholastic-rationalistic understanding of the creature-Creator relationship as found for example in Aquinas. Both Wolters $(1994: 52,53)$ and Ouweneel $(1993: 253,279)$ stress the dynamic of law. Ouweneel (1993:258) is very cautious about calling the law 'eternal', and is well aware of the danger of a distortion of creation order whereby it functions to preserve the status quo at all costs (Ouweneel, 1993:279, 280). Hart is thus too quick to associate Reformational understandings of creation order with rationalism; in many of his criticisms he is simply attacking a strawman.

Furthermore, the notion of a permanent creation order is not only the product of philosophical realism, but is a basic biblical idea, as biblical scholars are increasingly recognising. (See Stek, 1990; Scobie, 1991; Rogerson, 1991; Wenham, 1987:38; Dumbrell, 1984.) O'Donovan (1994:31) correctly recognises that

... to speak of this world as 'created' is already to speak of an order. In the first words of the creed, before we have tried to sketch an outline of created order with the phrase 'heaven and earth', simply as we say 'I believe in God the Creator', we are stating that the world is an ordered totality. By virtue of

Koers 60(2) 1995:189-212 
Critical issues in Reformational philosophy: a perspective

the fact that there is a Creator, there is also a creation that is ordered to its Creator...

This is supported by the Genesis creation account which moves from unordered to ordered creation via the 'Let there be's' (see Rogerson, 1991:58-63). The idea of permanent creation order is basic to all of the Bible so that Scobie (1991:188) is quite right in his proposal that God's order should be a major category in a biblical theology. Some understanding of order appears to be basic to any worldview (cf. Botha, 1994:1629), and even Hart argues for the creation of a new 'order' of compassion. The question appears to be not whether order is a central category in philosophy but which is the most biblical understanding of order.

Biblically creation order is not set against compassion in the way Hart does. The permanent order that results from God's 'Let there be's' is declared 'good' and, as Reformational scholars have long recognised law and Gospel are integrally and positively related. Hart discerns a tension between the portrayal of God as ruler in the Old Testament and God as Abba in the New Testament. This is a false tension and Spykman (1992:178) discerns the unity of the Testaments more accurately when he writes of creation order that "This network of structures and functions, governed by creational law, manifests his [God's] loving care for all creatures. ... The creation order is evidence of the caring hand of the Creator reaching out to secure the well-being of his creatures, of a Father extending a universe full of blessings to his children" (cf. Ouweneel, 1993:260, 261; Dooyeweerd, 1984:511-525 $5^{10}$.

Hart's view (1992b:22) that the law's only real power is to reveal sin and his setting of permanent order against compassion betrays a Lutheran Law-Gospel type dualism similar to Brunner's absolutisation of love which Dooyeweerd criticises (cf. footnote 10 above). In Brunner's absolutisation of love Dooyeweerd (1984:521) discerns a synthesis of Christian thinking with humanistic immanence philosophy. And in Hart's proposal for a new order centred in an ethos of compassion we appear to have a

10 Dooyeweerd (1984:512) is strongly critical of the Lutheran dualism of Law and Gospel and of Brunner for his absolutisation of love at the expense of justice. "From the Biblical point of view our answer is simply that the opinion of Brunner is not in keeping with the Biblical conception of the Law but stems from a semihumanistic point of view. A Christian must learn to bow before God's majesty and justice, which is not different from his love" (Dooyeweerd, 1984:521). 
synthesis of Christian thinking with the sort of historicism described by O’Donovan (1994:69, 70):

\begin{abstract}
A historicist account, on the other hand, must argue that this 'natural good' is not given transhistorically in nature at all, but is the product of cultural development peculiar to a certain time and place. .. By making marriage an item of cultural history in this way, historicism necessarily raises a question about it. ... Historicism makes all created goods appear putatively outmoded. So that if there are currents of dissatisfaction evident in a society's practice of marriage, such as might be indicated by a high divorce rate or a prominent homosexual culture, they will be treated with great seriousness as signs of the evolution for which the institution is destined.
\end{abstract}

Such historicism loses sight of the gap between God's kingdom and man's so that "To criticize the culture as a whole is unthinkable; one can only speak for the culture against the culture, as the representative of a new strand in the culture which will fashion its future (O’Donovan, 1994:73).

The danger of such a synthesis with historicism was made clear in Wolter's (1994) 1993 Stoker lecture on creation order. Wolters (1994:47) made the point that the modern worldview is unique in its denial of a creation order and maintains that

In the basic outlook of humanism, two fundamental themes of the biblical tradition were increasingly marginalised: creation as God-ordained order, and antithesis as the religious opposition to that order. This process of marginalisation culminated in Kant's 'Copemican revolution' and its heirs in German idealism and in what Alvin Plantinga calls the 'creative anti-realism' of much contemporary thought. Whatever order there is in the world is posited by man, not God, and the antithesis of biblical religion is domesticated or privatised, if not denied altogether.

Thus the stress within neo-Calvinism upon creation order and the antithesis represents a Biblical response to humanism and in particular to historicism. Dooyeweerd, for example is adamant that creation order is the bulwark against historicism. (See section 6 below for a further discussion of this.) According to my understanding of postmodernity, which I elaborate on below, the modernist root of human autonomy remains deeply entrenched in so-called postmodemity." The notion that humans create order is stronger than ever which suggests that the bulwark of creation order and the antithesis is more urgently required than before in the face of the historicism and relativism of the present postmodem hour. Wolters

II Cf. for example, the paradox in certain postmodem literary theory where the author cannot imprint his/her intention upon a text but the reader can create meaning. 
(1994:59) correctly identifies historicism as "the greatest ideological danger to face the Christian church since Gnosticism in the second century" and Hart is naive and wrong to argue that relativism is only a danger with a rationalist paradigm (Hart, 1992b:17).

Hart's view of creation order can also be critiqued in relation to his use of Scripture ${ }^{12}$, and his ready and somewhat uncritical espousal of much postmodern thought. Since both these aspects will be dealt with in following sections we will not pursue them here. Suffice to note that the idea of permanent creation order is central to the Reformational worldview, grace restores nature; and utterly central to Dooyeweerd's philosophy. To set compassion against order flies in the face of Scripture, the Reformed confessions and Reformational philosophy.

This is not for a moment to downplay compassion. It is, however, to insist that there are norms for compassion, which is as capable of being misdirected as any structure within God's good creation. Misdirected compassion can be deeply destructive while reformation according to God's good creation order is the door to restorative and transformative compassion. Reformational thinkers may be guilty of not going through this door enough but it remains the correct route. From some of Hart's statements ${ }^{13}$ one gets the impression that he has already decided what a compassionate approach to homosexuality is, and that any approach which compassionately opposes the life style while trying to develop redemptive counselling models and relationships which might bring a measure of healing (towards the male-female biblical norm) in homosexual's lives is automatically discounted as homophobic. This seems to me badly mistaken since for compassion to have teeth it must be undergirded by order.

If compassion 'transcends' order ... what is left of the content of compassion? Could we even recognise suffering as suffering if there was no order of which

12 Note here in particular Hart's stress on the fact that the images in which God becomes known remain open (Hart, 1992b:8). Such openness is important for Hart's position since it gives him the freedom to move away from the dominant Biblical metaphors of covenant and kingdom which strongly stress the will of the King and submission to it. The problem with this is that it radically reduces the authority of Scripture and allows Hart to reshape Scripture's message as he sees fit.

13 See for example Hart, $(1993: 173,174)$ where Hart states that, "no reading should apriori be suspect simply because it improves our relation to our homosexual neighbors". The assumption is that it is a pro-homosexual reading which will improve the Christian-homosexual relationship. 
it was a violation? Of course there is a radical difference between God's order and our own necessarily fallible human responses to that order. Certainly compassion must transcend fallen human order. But in doing so it must be guided by God's order, otherwise it could, at best, fail correctly to identify the needs of the sufferer (Chaplin, 1992:3, 4).

To set compassion against creation order is not a move we should make and particularly so at this time. There may well be room for reform of the Reformational view of creation but not, I suggest, in this direction.

\section{Antithesis}

One of the foundational areas of Reformational philosophy which Klapwijk (1988:103-106) regards as needing reassessment is the antithesis. He affirms the importance of the antithesis but seeks to redefine its implications for philosophy in terms of transformation rather than reformation. This approach to philosophy should, in his view, be based on assessment, arrest, and appropriation with the central category as transformation. He resurrects the notion of spolatio and focuses the direction of transformational philosophy in terms of sanctification compared with the secularisation of secular philosophy.

Elements of this transformational approach are not new to the Reformational tradition. Dooyeweerd took dialogue with contemporary philosophy very seriously and much of his philosophy has a spolatio aspect to it. Some years ago now, Seerveld (1960:8) referred to this aspect of Dooyeweerd's philosophy when he wrote of Dooyeweerd that he "is one of the best Reformed burglars alive; he has stolen a lot of Egyptian gold in his time, and he may have gotten dirty fingers. Kant has very very long arms, and Husserl's phenomenology is a seductive thing, and you cannot sleep off a South-West German hangover in one night". So how do Dooyeweerd and Vollenhoven differ from what Klapwijk is proposing? The difference is, I think, that because of their strong view of the antithesis both Dooyeweerd and Vollenhoven saw the need for the development of a philosophy driven by integrally Christian roots. If one imagines philosophy as a building, then the structure should emerge out of and take its direction from Christian foundations. For Vollenhoven this meant distancing himself more clearly from other philosophies whereas for Dooyeweerd this meant finding directions within contemporary philosophy that he could work with; both shared the urgent vision of an integrally Christian philosophy. 
With Klapwijk there has been a subtle shift. For him, transformational philosophy means that, "The idea of transformational philosophy excludes by definition, however, the possibility of a separate alternative circuit of Christian scholarly praxis because it proceeds on the basis of the dynamic notion of possessio" (Klapwijk, 1988:105). If I understand Klapwijk correctly, he wishes to focus Reformational philosophy away from the development of integrally Christian scholarship and towards transforming secular ideas. He does recognise the need for a Christian starting point in order to do this but this starting point is a Christian worldview and not a Christian philosophy (cf. Klapwijk, 1988:110).

As an Evangelical this seems to me a dangerous path to pursue. So much Evangelical scholarship has been of this sort; let so-called 'liberals' set the agenda and then we will fight according to their agenda and try and defend the cause where they create the battle. Within my field of Old Testament scholarship this has been the pattern for decades, with Evangelicals always taking a reactive rather than a proactive stance. The problem with this is that one never gets round to doing positive scholarship that is integrally Christian. Christian scholarship needs, of course, to be deeply in touch and in dialogue with secular trends, and to be busy with transformation, but this cannot be the heart of our direction. Re-formation of the sciences should remain our primary concern; this will always involve transformation but it will be more than that in its construction of integrally Christian scholarship. As Seerveld put it in his workshop at the 1994 Dooyeweerd centenary conference, synthesis may be our practice but it should never be our policy. Scripturally led believers do have a headstart in their orientation to the truth and as Kuyper (1902-1905, 3:527) indicated: "What we really need is a seedling of scientific theory thriving on christian roots. For us to be content with the act of shuffling around in the garden of somebody else, scissors in hand [to cut the other's flowers], is to throw away the honour and worth of our christian faith."

I have wondered what motivates the shift from reformational to transformational, and my suspicion is that it is related to a diminished view of idolatry. Within the work of Dooyeweerd and especially of Vollenhoven, there is an acute sense of the dangerous implications of idolatrous seduction. Writing about Vollenhoven, Seerveld (1960:7) says

Time and again I came to Vollenhoven with the texts of a philosopher, like Pilate coming before the Jewish high priests: I find no fault in this man, he does not have a modified pagan conception, let him go. Patiently, painsta- 
kingly, Vollenhoven would probe the texts, his scalpel moving firmly, surely, and soon I would see the thinker who had enamoured me dissected and bare. Every philosopher worthy of the name, in his human pride, tries to put God in his pocket and tie all creation up in a neat little system. The result is: he lands in a compartment on Vollenhoven's chart. Wonderful irony.

With the work of Vollenhoven, Dooyeweerd, Seerveld and the likes, one gets a strong sense of the perils of idolatry and the urgency of integrally Christian scholarship. That sense is not nearly so clear in the recent work of Klapwijk and Hart. Hart (1992b:19) for example, reflecting on the contemporary inspiration of believers and 'the future of the Spirit' comments quite uncritically that, "To reflect on this we have developed theologies of process, of hope, and of liberation. These are not departures from the truth, but only developments beyond where we had gotten". And a strong sense of antithesis is not popular in 'postmodernity'. Modernity had a strong sense of truth, albeit a rationalist one. That has been undermined in 'postmodernity' in which all is in flux and uncertain. A commitment to 'true truth' is alien to much postmodern thinking with its celebration of pluralism and multiculturalism. In this respect Klapwijk and Hart seem to me to be in danger of succumbing to the spirit of the age, whereas, paradoxically, our age requires a strong reassertion of the antithesis. Our temptations do need to be shown to us, and a strong sense of the battle in each area of life is required for such illumination.

\section{The authority of Scripture}

Klapwijk (1988:106) identifies the relationship between Scripture and philosophy as an ongoing area of controversy in De Vereniging voor Calvinistische Wijsbegeerte. He traces this divergence of opinion back to the differences between Dooyeweerd and Vollenhoven. Vollenhoven makes direct appeals to Scripture whereas Dooyeweerd came more and more to relate the authority of Scripture in philosophy to the ground motive of creation, fall and redemption which should permeate the whole of Christian experience, including scholarship irrespective of appeal to individual biblical texts. I have heard the story told of Vollenhoven meticulously checking every biblical reference to 'heart' to confirm his reading of the biblical notion of heart. Dooyeweerd increasingly stressed the role of Scripture in philosophy as driving power; Van Eikema Hommes, his successor, took this even further by completely rejecting external points of contact between biblical revelation and scientific problems. (For references to these scholars see Klapwijk, 1988.) In 

Riessen make regular appeal to the Bible in their philosophical work. Clearly, there are important differences among Reformational scholars with respect to the relationship between Scripture and philosophy.

Klapwijk $(1988: 108,109)$ locates the key to understanding the differences between these positions in the mediating role played by the historical tradition of the Calvinist worldview between Scripture and philosophy. Referring to the encouraging degree of agreement on what Scripture teaches despite the different views of the role of Scripture, Klapwijk (1988:108) comments that

\begin{abstract}
... these convictions which they and we hold to a great extent in common have not simply fallen out of the sky like the Black Stone in Mecca. They are convictions which have sprung from or crystallised within a common Christian tradition, that of the calvinist reformation of the sixteenth century and the nineteenth-century reveil. ... I come finally to what I call the 'missing link' in the discussions that have been carried on within the Association for decades now about the relationship between the Bible and philosophy: the mediating role played in this relationship by the so-called life and world-view. Thus Vollenhoven could speak of 'scriptural philosophy'and Dooyeweerd could mention a 'central ground motive' as long as it was not forgotten that in doing so they understood 'scriptural'and 'biblical' within the historical tradition of the 'calvinist' worldview. The context provided by this worldview (which perhaps bore more strongly the stamp of self-evidence for them than it does for us) can be traced in retrospect as the binding element.
\end{abstract}

Klapwijk focuses on the historical roots of Reformational philosophy in the neo-Calvinistic worldview. Within Reformational philosophy $\mathrm{Al}$ Wolters $(1985$; 1989) has done considerable work on the systematic relationship between worldview and philosophy and Klapwijk (1988:109) acknowledges this, but maintains that in Creation Regained (Wolters, 1985) it remains unclear whether worldview plays a mediating role between religion and philosophy only in historical or also in systematic perspective. Wolters, I expect, would answer, in systematic perspective as well, and would identify the neo-Calvinist worldview as Scriptural. Klapwijk, however, is uncertain here and in the process alerts us, I think, to a key issue in the Scripture-philosophy debate. A common Calvinistic worldview bound Dooyeweerd and Vollenhoven together, even if tacitly so, and this was certainly more than simply the driving power of the creation, fall, redemption ground motive. Among the following generations of Reformational philosophers that worldview has been eroded for a host of reasons and with serious consequences. 
C. G. Bartholomew

Perhaps because much that Dooyeweerd and Vollenhoven held in common was tacit and assumed and not always articulated, it has been possible for disciples of theirs to articulate similar positions while moving away significantly from the direction of their philosophical work. Inherent to the Reformed tradition is a high view of the authority of Scripture and a distrust of experience where the latter conflicts with Scripture. Confessionally this is well articulated in the Belgic Confession and the Heidelberg Catechism. ICS reflects the influence of this tradition in its educational creed in which it refers to the Word of God as understood by the Reformed confessions. And it is out of such a view of Scripture that the Reformational focus on the sovereignty of God, the law idea and the neoCalvinist idea of creation order arise. Groen van Prinsterer's, Kuyper's and Bavinck's Reformed views of Scripture are easy to document. This high view of Scripture is the soil out of which Reformational philosophy has grown - without this soil there would be no such philosophy. Now, however, this soil is being eroded.

The text that seems to me to most clearly manifest this erosion is Hart's Setting our Sights by the Morning Star, subtitled "Reflections on the Role of the Bible in Post-modern Times" $(1989)^{14}$. This is a popular work in which Hart outlines his pastoral strategy for reading the Bible in our postmodern era in such a way that we experience the light of Jesus directing our lives.

The concern in postmodernity is with practical life direction rather than doctrine and, according to Hart, we therefore need an understanding of the Bible which relates to this. In modernity Christians found the image of infallibility particularly helpful but that is no longer the case.

There was a time when we were seriously bothered primarily by mistakes in understanding, errors of the intellect. Today we are first and foremost bothered by erring in the sense of wandering: being lost in the dark. Much terrain over which we travel today is uncharted. That being so and the times being dark, we are most helped by light (Hart, 1989:21).

Foregrounding the image of the Bible as light is also justified because light holds many interrelated meanings within and to the Scriptures together,

14 My focus in what follows will be on Hart's biblical hermeneutical proposals. For a taste of Hart's work on a specific text see his work on Romans I (Hart, 1989:222$230 ; 1992 \mathrm{a} ; 1993)$.

Koers 60(2) 1995:189-212 
and by its focusing the relationship between Jesus, the light and the lamp light of the Bible.

So the bright light of Jesus differs from the lamp light of the Bible. ... the truth of the new light differs from the old because it is already present, rather than only promised. It is present not only in Christ, but also in the hearts of believers. ... The light shines brighter in a life testifying of God's love in Jesus than in the Bible (Hart, 1989:26).

The distinction between the Bible as light and Jesus as light is central to Hart's hermeneutic.

We will do well to view Scripture as a lamp which points us to the light that Jesus is. The texts that speak to us in this context tell us about new life, liberation, reconciliation, peace, joy, and justice: key concerns of people in our time. But the specifics in which the light is reflected in the Bible are not identical with that light. They reflect the light for its own time. Only in Jesus does the light shine fully. In the light of Jesus the Bible allows us to go beyond its own text to keep us moving on the road of redemption (Hart, 1989:41).

Central to Hart's distinction between Jesus and the Bible is his understanding of 2 Peter 1:19, from which verse his book gets its title. 2 Peter 1:19 says, "So we have the prophetic message more fully confirmed. You will do well to be attentive to this as to a lamp shining in a dark place until the day dawns and the morning star rises in your hearts". Hart (1989:25) understands the morning star to already have risen in our hearts and thus places great emphasis on our experience of Christ in the Spirit. It should be noted that this is a most unusual understanding of 2 Peter 1:19. The rising of the morning star to which 2 Peter refers is clearly future and referring to the return of Christ. ${ }^{15}$ Peter's point is that until Christ returns we do well to take the Bible very seriously as God's Word.

In the process of seeing the Bible as a reflection of and pointing to the greater light of Jesus, Hart privileges the role of the believer and her experience in the hermeneutic process. He makes much of the indwelling of believers by the Spirit and the light of Jesus. In his view our orthodox tradition has not given much prominence to the role of the Spirit in the experience of believers. If " truth' in the Bible is 'being lead by the Spirit on paths of love', then to discern whether we are led by the Spirit in our experience is in fact discerning the truth" (Hart, 1989:32.) Believers have in them the light of Jesus and this is superior to the lamp light of the Bible:

15 Cf. Kelly, 1969:315-325; Bauckham, 1983:223-227; Green, 1968:86-92. 
C. G. Bartholomew

Light is incredible. Its power, glory and life are so great that even the Bible, as became clear, is not called a light. It is just a lamp, says Psalm 119. 'Hang on to it,' says Peter, 'as you would to any lamp in a dark place. But a lamp is just a flickering, smoking oil flame. So if the Morning Star should rise in your hearts, that would really be light.' Though the Bible is no more than a lamp, an oil lamp, we ourselves, followers of Jesus, followers of the Morning Star, are called to be lights. Jesus, the light of the world, calls us the light of the world (Hart, 1989:64).

This privileging of the believer is further buttressed by Hart's assigning of apostolic authority to the contemporary Christian. He finds analogies to the authority we posses in 1 Corinthians 7 and texts like Acts 10,11 (cf. Hart, 1989:160-166). Consequently, "We need to have Paul's courage and by the Lord's mercy, trusting the Spirit leads us, stipulate traditions, rules, laws, customs, orders for life in our times" (Hart, 1989:161). In this way believers can be inspired in a way similar to the Bible:

When the Spirit whose ways these were is also our Spirit, we will find that not only are these Scriptures inspired, but so are believers who read them in their own time. Only if the Bible and believers are moved by the Spirit (inspired!) today will the life of the Spirit come through biblical guidance (Hart, 1989:156).

How does this pastoral strategy of Hart's work out in practice in letting the Bible direct us in today's world? Morning Star contains many examples; here I use one to illustrate Hart's method. Hart reflects upon the narratives in 1 Samuel about the emergence of kingship in Israel. Samuel is reluctant to grant the Israelites request for a king but eventually God tells him to go ahead. From this we learn that

If our next generation seems embarked on a turn of events from which we probably can't stop them, even when in faith we believe that it upsets God, we may still have to consider God telling us to 'obey them, listen to them, hear their voice, their cry'. We may be anxious, fearful or angry. But it is possible that we may need to hear a call come to us to help them observe God's ways in that doubtful path they choose to go. They fear institutionalized marriage when they see what we make of it. We can support them in being spiritually responsible if they think living together is their way to go. We could tell them that faithfulness in love, God's way, has a power that outlasts all institutions. ... In God's advice to Samuel to stress the people's cry rather than God's disappointment there may be advice to us to trust the next generation's ability to find their way to God with God, though their mode of travel and route chosen may not be ours (Hart, 1989:50, 51).

I have quoted at length from Morning Star in order to allow Hart to speak in his own words as much as possible. Positively Hart focuses the ques-

Koers 60(2) 1995:189-212 
tion of how the Bible functions authoritatively for believers and he also explores the influence of modernity upon believers' views of Scripture. However, it should be apparent that his hermeneutics represents a radical shift from traditional Reformed or generally orthodox views of the Bible. Indeed Hart's view is quintessentially modern in its reduction of the Bible to lamplight and its privileging of experience and trust in the authority of believers. His approach is deeply subjective, pneumatological in a way far from the Reformed holding of Word and Spirit together ${ }^{18}$, at the mercy of historicism and relativism and, it seems to me, in the grip of postmodem ideology ${ }^{17}$.

\title{
6. Modernity and postmodernity
}

After being at the ICS for a while it became apparent to me that if I was to understand what was going on there I would have to work at understanding so called 'postmodernity'. Many of the proposed shifts were being justified in terms of our changed context. In Morning Star for example, referring to the shift from a focus upon the Bible as inerrant/infallible to the Bible as light Hart (1989:209) suggests that

\begin{abstract}
Perhaps the greatest problem related to moving away from inerrant infallibility is that it instils a fear of relativism. ... relativism is a name for views of truth given to those views from the point of view of rationalism. Trust in truths of reason makes a life without that trust seem relativistic to those who have that trust. Strictly speaking a relativist would hold that any view is as good as another: there is no absolute standard. But no one holds that. ... Relativism is a rationalist scare.
\end{abstract}

Hart thus partially justifies his hermeneutics for understanding the Bible in terms of rationalism no longer being the dominant paradigm of our day.

16 A comparison of Hart's view of the relationship between Scripture and the Spirit with that of Calvin is most revealing. For Calvin (cf. Institutes, Book 1 section 2) we recognise the Spirit by his agreement with Scripture. For Hart the relationship is practically reversed since what is normative in Scripture is discerned by its agreement with the Spirit.

17 There is no problem with the use of light as the metaphor for Scripture. It helpfully alerts us to Scripture as 'glasses' to help us to find our way in Gods's world and to read his Word-structured world correctly. Scripture must not be overloaded as the only Word of God but must be integrally related to God's Word in Christ and his Word which structures creation. However, as Spykman (1992:87, 88) so clearly points out, Scripture must be privileged epistemologically. Hart uses the image of light in a way that undermines the foundational role of Scripture. 
C. G. Bartholomew

Change and flux are prominent postmodem themes ${ }^{18}$ and they seem to shape Hart's thinking. Speaking of our need to trust the Spirit in the way it leads us Hart (1989:169) comments that "God's presence in the norms the Spirit gives us does not need to be unchangeable, an immutable absolute, in order to be trusted ... For us the idea of something that never ever changes in any way no longer fits our experience". Where this kind of thinking takes Hart is evident in his stance on homosexuality:

\begin{abstract}
Whenever a norm-principle is specified, the concrete rule needs to be one we can actually follow. A rule or norm which is not followed by most people indicates that we need a re-formulation. ... Morality for heterosexual people cannot be helpful for people who are not heterosexual. They will need different strategies to be moral. We all need to get around, we all need to be moral. But precisely in order to achieve that, we need different rules (Hart, 1989:141).
\end{abstract}

Postmodern thinking is also evident in Hart's privileging of compassion at the expense of creation order, his undermining of the antithesis and in his indeterminate view of textuality which he applies inter alia to the Bible. ${ }^{19}$ It seems clear to me that so-called postmodem ideas have contributed integrally to Hart's reshaping of the Reformational tradition. There is an interesting parallel here in the thinking of Klapwijk. He starts his proposals for the reconsideration of the fundamentals of the Reformational tradition with a statement that our world is drastically and fundamentally different to that of Vollenhoven and Dooyeweerd (Klapwijk, 1988:101103). This shift in context underlies Klapwijk's proposal for transformational rather than reformational philosophy:

The idea of transformational philosophy is grafted to this world situation. Transformational philosophy taken in the Christian sense presents itself in all modesty as a philosophy in loco: a philosophy 'at the spot'. It does not install itself beforehand in some supposed process of universal culture or of Western

18 Cf. Harvey's analysis of postmodernity and our further comments about Harvey's analysis below.

19 See Hart (1993). In his dialogue with Wolters about Romans 1 he (Hart, 1993:170 says that, "I am not concemed to point out that a traditional reading is wrong. Nor that a possible reading that occurs to me is right or that we must use this reading. I rarely believe that in significant instances the right reading of a text is a matter of proof. ... Various possible readings could plausibly exist side by side for some time, possibly even incompatible ones." Cf. also Hart (1992b:5, footnote 13), in which Hart describes as Platonic the hermeneutics which seeks the true reading of a text.

Koers 60(2) 1995:189-212 
developments $a$ la the high flown model of Hegel and his followers. It takes the concrete historical situation, including its intellectual heritage, as its hermeneutical starting-point and the creational-messianic perspective as its transformational guideline (Klapwijk, 1988:130).

The extent to which a particular view of postmodernity is at work in Hart and Klapwijk's rethinking of the tradition is particularly clear in their reassessment of creation order which we described above. Dooyeweerd was clear about creation order as the bulwark against historicism. Chapter three of Roots (1979) opens with these strong words:

Historicism is the fatal illness of our 'dynamic' times. There is no cure for this decadent view of reality as long as the scriptural creation motive does not regain its complete claim on our life and thought. Historicism robs us of our belief in abiding standards; it undermines our faith in the eternal truth of God's Word. Historicism claims that everything is relative and historically determined, including one's beliefs in lasting values.

Bid it halt before the gates of your faith, if you wish. The demon of historicism will not be shut out so easily. He has bribed your watchmen without your knowing it. Suddenly he stands in your inner chamber and has you in his power. He asks: do you claim that Holy Scripture discloses eternal truth? ... To be at home in these times you must place yourself midstream in the movement of history. To be listened to today you must be open to the spirit of the age. ... These are the surreptitious ways in which historicism enters the heart of modem man. Some unsuspecting theologians accepted its claims insofar as temporal reality was concerned but tried to preserve the eternal value of Christian truths. This, however, was a formidable mistake. ... historicism is driven by a religious ground motive that takes its stance in radical opposition to the ground motive of the christian religion (Dooyeweerd, 1979:61, 62).

Is Dooyeweerd caught in a rationalist paradigm to the extent that he discerns a non-existent danger in historicism? Or is Hart one of the watchmen that has been bribed without knowing it? If Harvey (1990) is correct in his analysis of modernity as characterised on the one hand by the rejection of tradition and espousal of change, and on the other by the confidence that rational analysis would arrive at absolute truth, and of postmodernity as that period in which the second pole has been thoroughly undermined so that flux and change become the dominant scenario, then it becomes clear that historicism is a greater threat than it ever was in Dooyeweerd's time.

What is extraordinary is that rather than the resources of the Reformational tradition being used to counter this threat, the tradition is being 
C. G. Bartholomew

bowdlerized by its own philosophers ${ }^{20}$. This buckling before the spirit of the age is the very thing for which the Reformational tradition was developed to guard against. Few Christian traditions have the resources to tackle the modernity/postmodernity issue that the Reformational tradition has, and it is imperative that these resources are put to good use. ${ }^{21}$

\section{Conclusion}

Particularly here in South Africa, the present is a time ripe for Reformational thinking and activity ${ }^{22}$. The critical issues we have identified are fundamental ones and could seriously impair Reformational progress in South Africa and Africa if mishandled. The Reformational tradition needs to be preserved, handed on to the emerging generations of Africans, deepened, and further reformed, and Reformational philosophy has a crucial role to play in that process. In this respect we could speak of the unfulfilled potential of the Reformational movement in Africa; not that nothing has been achieved - much has been done - but that so much remains to be done. But in order for this to take place we need to be clear what the Reformational tradition is and what it is not. We need boundaries to facilitate the progress of the real work that needs to be done: scholarship and activity coram Deo.

\section{Bibliography}

BAUCKHAM, R.J. 1983. Jude, 2 Peter. Texas : Word. (Word Biblical mentary, volume 50.)

20 This is not for a moment to suggest that all that is postmodern is bad. Cf. Lyon (1994), Samson et al. (1994), and Lundin (1993) for useful and balanced understandings of the good and bad sides of the postmodem shift. In many ways postmodernity provides opportunities for Christian voices to be heard as they never could be in modemity. My critique at this point is that the Christian thinkers referred to are in danger of succumbing to the negative sides of postmodern thinking.

21 Cf. for example Wolters (1992:16) on the promise of the neo-Calvinist tradition with respect to historicism.

22 Of course the time is always ripe for Reformational activity, but the demise of apartheid and of Communism make the present a particular time of opportunity in Africa. 
Critical issues in Reformational philosophy: a perspective

BARTHOLOMEW, C.G. 1994a. Response to Al Wolters' Paper. (In Schrotenboer, P.G., Troost, A., Van der Kooi, C., Spykman, G., Wolters, A., Bartholomew, C.G. God's Order for Creation. Potchefstroom : IRS. p. 61-70.)

BARTHOLOMEW, C.G. 1994b. Pro Rege and the Third Millenium. Unpublished paper.

BOTHA, M.E. 1994. Understanding Our Age. Philosophy at a Turning Point of the 'Turns'? - The Endless Search for the Elusive Universal. Tydskrif vir Christelike Wetenskap, 30(2): 16-31.

CALVIN, J. 1960. Institutes of the Christian Religion. 2 volumes. Edited by McNeill, J.T. Philadelphia : Westminister Press.

CHAPLIN, A. \& J. 1992. Summation. Unpublished. Conference on 'An Ethos of Compassion and the Integrity of Creation.' Institute for Christian Studies, Toronto, 3-6 June 1992.

DOOYEWEERD, H. 1954. The Secularization of Science. Memphis : Christian Studies Centre.

DOOYEWEERD, H. 1979. Roots of Western Culture. Pagan, Secular and Christian Options. Toronto : Wedge.

DOOYEWEERD, H. 1984. A New Critique of Theoretical Thought. 2 volumes. Canada : Paideia Press.

DUMBRELL, W. 1984. Covenant and Creation. An Old Testament Covenantal Theology. Lancer : NSW, Australia.

GREEN, M. 1968. 2 Peter and Jude. Leicester : IVP. (Tyndale New Testament Commentaries.)

HART, H. 1989. Setting our Sights by the Morning Star. Reflections on the Role of the Bible in Post-modem Times. Toronto : Patmos Press.

HART, H. 1992a. Romans Revisited. The Other Side, 28(4):56-62.

HART, H. 1992b. Creation Order in Our Philosophical Tradition. Critique and Refinement. Unpublished. Conference on "An Ethos of Compassion and the Integrity of Creation". Institute for Christian Studies, Toronto, 3-6 June 1992.

HART, H. 1993. Reply to Wolters. Calvin Theological Journal, 28(1):170174.

HARVEY, D. 1990. The Condition of Post-modernity. Oxford : Blackwell.

KELLY, J.N.D. 1969. A Commentary on the Epistles of Peter and of Jude. London: A. \& C. Black.

KLAPWIJK, J. 1987. The Struggle for a Christian Philosophy: Another Look at Dooyeweerd. Tydskrif vir Christelike Wetenskap, 23(1-2): 81-98.

KLAPWIJK, J. 1988. Reformational Philosophy on the Boundary between the Past and the Future. Philosophia Reformata, 53:101-134. 
C. G. Bartholomew

KLAPWIJK, J. 1989. On Worldviews and Philosophy: A Response to Wolters and Olthuis. (In Marshall, P.A., Griffoen, S., Mouw, R.J. eds. Stained Glass. Worldviews and Social Science. Lanham, New York : University Press of America. p. 41-55.)

KUYPER, A. 1902-1905. De Gemeene Gratie. 3 volumes. Kampen : Kok.

LUNDIN, R. 1993. Christian Faith and the Postmodern World. Grand Rapids : Eerdmans.

LYON, D. 1994. Postmodemity. Buckingham : Open University Press.

O'DONOVAN, O. 1994. Resurrection and Moral Order. An Outline for Evangelical Ethics. 2nd ed. Leicester : Apollos.

OLTHUIS, J. 1992. When is Sex against Nature? Unpublished paper. Conference on "An Ethos of Compassion and the Integrity of Creation." Institute for Christian Studies, Toronto, 3-6 June 1992.

OUWENEEL, W.J. 1993. A Critical Analysis of the External and Internal Prologomena of Systematic Theology. 2 volumes. Bloemfontein : UOFS. (D. Th. thesis.)

ROGERSON, J. 1991. Genesis 1-11. Sheffield : JSOT Press. (Old Testament Guides.)

SAMPSON, P., SAMUEL, V. \& SUGDEN, C. eds. 1994. Faith and Modernity. Oxford : Regnum Lynx.

SCOBIE, C.H.H. 1991. The Structure of Biblical Theology. Tyndale Bulletin, 42(2):163-194.

SEERVELD, C. 1960. Voor en uit de practijk. Correspondentie-bladen van de Vereniging voor Calvinistische Wijsbegeerte, 24(1):5-10.

SPYKMAN, G. 1992. Reformational Theology. A New Paradigm for Doing Dogmatics. Grand Rapids : Eerdmans.

STEK, J. 1990. What Says the Scripture? (In Van Till, H. ed. Portraits of Creation: Grand Rapids : Eerdmans. p. 203-265.)

WENHAM, G. 1987. Genesis 1-15. Texas : Word. (Word Biblical Commentary, 1.)

WOLTERS, A. 1985. Creation Regained. Biblical Basics for a Reformational Worldview. Grand Rapids : Eerdmans.

WOLTERS, A. 1989. On the Idea of Worldview and Its Relation to Philosophy. (In Marshall, P.A., Griffoen, S. \& Mouw, R. eds. Stained Glass: Worldviews and Social Science. Lanham, New York : University Press of America. p. 14-25.)

WOLTERS, A. 1992. Creation Order: An Historical Look at Our Heritage. (In Schrotenboer, P.G., Troost, A., Van Egmond, A., Van der Kooi, C., Spykman, G.J., Wolters, A., Bartholomew, C.G. 1994. God's Order for Creation. Potchefstroom : IRS. p. 42-61.)

WOLTERS, A. 1993. Hart's Exegetical Proposal on Romans 1. Calvin Theological Journal, 28(1):166-170. 
